\title{
Application of Data Quality Indicator of Carbon Footprint and Water Footprint
}

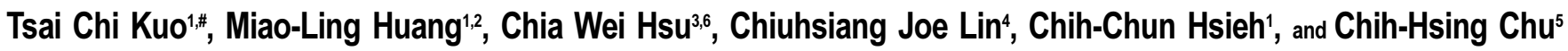 \\ 1 Department of Industrial and Systems Engineering, Chung Yuan Christian University, Chung Li, Taiwan, R.O.C., 302 \\ 2 Department of Industrial Management, Chien Hsin University of Science and Technology, Taiwan, R.O.C., 302 \\ 3 Department of Travel and Eco-tourism, Tungnan University, New Taipei City, Taiwan, R.O.C., 222 \\ 4 Department of Industrial Management, National Taiwan University of Science and Technology, Taiwan, Taiwan, R.O.C., 106 \\ 5 Department of Industrial Engineering and Engineering Management, National Tsing Hua University, Hsinchu, Taiwan, Taiwan, R.O.C., 300 \\ 6 Department of Business Administration, National Central University, Taoyuan, Taiwan, Taiwan, R.O.C., 320 \\ \# Corresponding Author / E-mail: tckuo@cycu.edu.tw, TEL: +886-3-2654421, FAX: +886-3-2654449
}

\begin{abstract}
To mitigate the impact of global warming on the environment, many governments, non-profit organizations, and enterprises have formulated relevant standards to assist enterprises in promoting carbon management, and to encourage the design and popularization of low-carbon products. These standards include: PAS 2050, ISO/TS 14067 and so on. Under these initiatives, enterprises try to disclose the carbon and water footprints of the products based on the life cycle. Some enterprises argue and debate that there exists uncertainty of the footprints calculation since the data collection is not systematically. To solve this problem, in this research, the calculation of carbon footprint and water footprint are evaluated with the data quality indicator (DQI) management system. The collected data is evaluated based on the footprint calculation methods. Also the pedigree matrix is constructed as an aide to solve the data uncertainty that included reliability, completeness, times, geography, and technologies differences. Through the DQI, the carbon footprint and water footprint are not only calculated simultaneously, but also correctly. The results could be the reference for products' environmental improvement.
\end{abstract}

\section{Introduction}

The ecological footprint (EF) represents the critical natural capital requirements of a defined economy or population in terms of the corresponding biologically productive areas. ${ }^{1} \mathrm{EFs}$ have been used as the world's premier measure of human demand on nature. Based on the ecological footprint analysis, the environmental problem is very urgent to be solved. However, some researchers do not perform the research based on the environmental problem, especially in supply chain problems. $^{2,3}$

Among the ecological footprint family, global warming and water resource shortage problems are highly emphasized. Therefore, carbon footprint (CF) and water footprint (WF) are the major indicators of the footprint family. Several researchers have proposed the scientific methods to solve the GHG emissions and water resource problems. ${ }^{4-7}$ The enterprises use the tools, such as life cycle assessment (LCA), to evaluate the greenhouse gas (GHGs) and water information of products, and further to reduce their emissions and consumption. CF and WF can be employed at a wide scale, ranging from a product and process up to individuals, cities, nations, as well as the whole world. ${ }^{8}$ Based on the definition by Intergovernmental Panel for Climate Change (IPCC), CF is an indicator of anthropogenic greenhouse gas emissions. ${ }^{9} \mathrm{WF}$ is a consumption indicator of freshwater use that quanties direct and indirect volumes. ${ }^{10} \mathrm{WF}$ includes three components: the green, blue, and gray water footprints. Since CF and WF cover the whole product life cycle stages (raw material, manufacturing, distribution, use, and disposal), some enterprises also use CF and WF to evaluate the product design, production efficiency, and supply chain management. As shown in Fig. 1 (a) and 1 (b), the Coca Cola Company investigated $\mathrm{CF}$ and $\mathrm{WF}$ of its products ${ }^{11,12}$ and found that $30 \% \sim 70 \%$ GHG comes from the package of products. Therefore, Coca Cola developed less environmental impact materials, such as recycle material, for its products package.

In the past, several enterprises have spent a lot of cost and human resources on $\mathrm{CF}$ and WF projects to reduce the environmental impacts. The principles and contents of CF and WF projects are not totally the 
same, while their methodologies of data collection and analysis are similar. It is needed for both $\mathrm{CF}$ and WF projects to investigate the whole supply chain. Therefore, it is important for the enterprises to construct a hybrid $\mathrm{CF}$ and $\mathrm{WF}$ analysis system to reduce the inventory time and cost. Thus, the engineers could employ the data of the hybrid system to design a "green" product. The supply chain manager also could environmentally and sustainably manage their suppliers.

The purpose of this research was to analyze the similarities and differences of aspects such as definition, methods of measurement, spatiotemporal dimensions, components, and entities for which the footprints can be calculated. The product's bill of material (BOM) was also investigated the analysis of life cycle inventory (LCI) based on the guidelines of $\mathrm{CF}$ and WF. The data quality system was also developed to increase the data quality of CF and WF. Finally, a case study of a notebook was presented to illustrate the framework of products' CF and WF.

\section{Literature Review}

\subsection{Life Cycle Assessment}

The enterprises used LCA as a tool to make the environment decisions for the practical purposes of (1) environmental strategy planning and development, (2) product design and process optimization and innovation, (3) identification and improvements environmental impacts, (4) environmental reporting, declarations, and marketing, and (5) creation of a framework for environmental audits. LCA developed the profession theories for its concept ${ }^{13,14}$ and practical textbooks. ${ }^{15}$ Chiu and $\mathrm{Chu}^{16}$ analyze the review on integrated sustainable product design from life cycle perspectives.

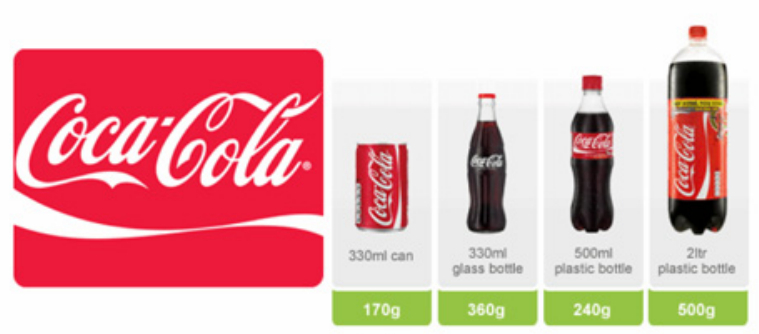

(a)

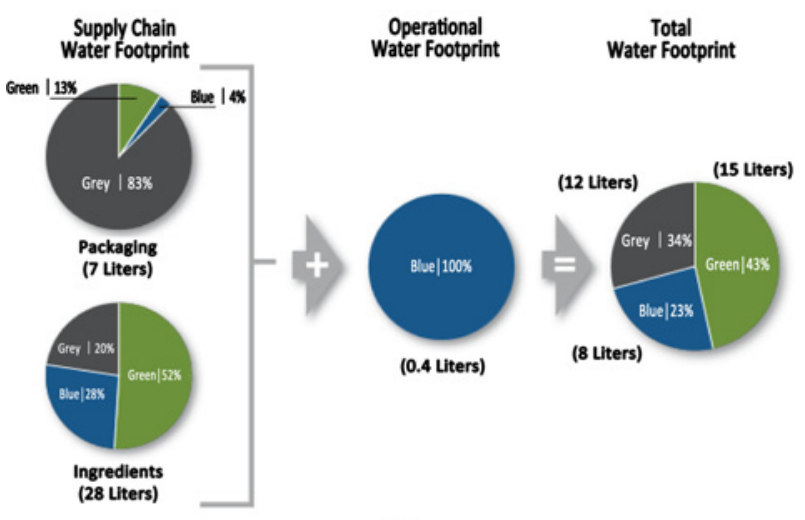

(b)

Fig. 1 (a) Carbon footprint of Coca Cola, (b) water footprint of Coca Cola

\subsection{Carbon Footprint}

Carbon footprint is a measure of a product's impact on the environment, in terms of greenhouse gases (GHGs) emitted along its supply chain. ${ }^{17,18}$ Most enterprises follow the guidelines of ISO 14064 (published in 2006) standard and PAS $2050^{19}$ for calculating the carbon footprint of a product or service. Five steps to ascertain the carbon footprint are summarized as: (1) product analysis, (2) mapping of supply chain process, (3) setting of boundary system for assessment, (4) identification and collection of data, and (5) assessment of product carbon footprint. ${ }^{20}$ The most difficult of carbon footprint measure is to perform the life cycle inventory. A carbon footprint inventory contains the amount of GHG emitted from the exploitation and manufacturing of raw materials, as well as manufacturing, assembly, use, discard, and recovery of products. Several researchers attempted to urge enterprises to concern about $\mathrm{CO}_{2}$ emissions, and proposed improvement strategies for carbon footprint. ${ }^{21,22}$

\subsection{Water Footprint}

Consumption over freshwater resources has been discussed during decades. It is because of growing population, economic growth, increased demand for agricultural products for both food and non-food use, and a shift in consumption patterns towards more meat and sugar based products. ${ }^{23}$ The water footprint approach was proposed to measure the volumes of water use and pollution, as well as the locations. Generally, the water footprint of a product is the volume of freshwater used to produce the product, measured over the full supply chain. The WF concept was first introduced by Hoekstra, ${ }^{24}$ and subsequently elaborated by Chapagain and Hoekstra $^{25}$ as an indicator of human appropriation of freshwater resources. It incorporated both direct and indirect water use of a consumer or producer. WF is the total volume of freshwater used to produce the product, summed over the various steps of the full supply chain. Generally, the water footprint includes blue water footprint, green water footprint, and grey water footprint. Table 1 listed the carbon and water footprints.

(1) Blue water footprint refers to consumption of blue water resources (surface and ground water) along the supply chain of a product. 'Consumption' refers to loss of water from the available ground-surface water body in a catchment area, which happens when water evaporates, is incorporated into a product or returns to another catchment area or the sea.

(2) The green water footprint refers to consumption of water from rainwater stored in the soil as soil moisture.

(3) The grey water footprint refers to pollution and is defined as the volume of freshwater that is required to dilute the loading of pollutants based on existing ambient water quality standards.

$\mathrm{Li}$ and $\mathrm{Chen}^{32}$ proposed a hybrid method to evaluate the water footprint of gaming industry in water scarce Macao. The calculation is based on the latest statistics and most exhaustive embodied water intensity databases. Jefferies et al., ${ }^{33}$ used two main approaches enabling such a comprehensive products assessment, namely WF and LCA. Jefferies et al., ${ }^{33}$ also identified the similarities, differences and synergies at both the water accounting and impact assessment levels. The calculation of CF and WF is somewhat different; however, the methodologies are almost the same. 


\subsection{Data Quality}

Uncertainty analysis should be addressed when performing life cycle assessment. Generally, life cycle inventory (LCI) data were investigated using case studies on different products. However, due to different production processes and the lack of detailed production data, there are signicant variations in different LCI databases. ${ }^{34}$ This type of variations is called data uncertainty. To solve the variations, the statistical and Data Quality Indicator (DQI) methods have been used to estimate data uncertainties in LCA. Data quality is the specific characteristic of data collection background, sometimes called meta data, such as information on its uncertainty, reliability, and its completeness, its age, the geographical area for which the data is representative and the process or technological level for which the data is representative. Weidema and Wesnaes ${ }^{35}$ proposed a pedigree matrix to assess data quality in LCA. Ciroth $^{36}$ modified the matrix and addressed cost data quality issues for eco-efficiency measures. Wang and Shen $^{34}$ proposed a hybrid Data Quality Indicator and a statistical method for improving uncertainty analysis in LCA of complex system.

\section{Methods and Data}

The evaluation method of carbon footprint includes (1) scoping, (2) data collection, (3) footprint calculation, and (4) interpreting results and driving reduction (PAS 2050). The assessment of water footprint consists of four distinct phases: (1) setting goals and scope, (2) water footprint accounting, (3) water footprint sustainability assessment, and (4) water footprint response formulation. Fig. 2 indicates a hybrid calculation of carbon footprint and water footprint for this study. Also, the data quality indicator was added to reduce the data uncertainty.

\subsection{Step 1: Goal and Scope}

It is important to determine the purposes and contexts of carbon and water footprints. Generally, the product data, identification of all materials, activities, processes, and emissions, should be collected at different stages of the life cycle. In order to measure the footprints, the scope and boundary should be defined first.

(1) cradle-to-grave quantification, also known as business to consumer (B2C), includes the emissions and removal arising from the full life cycle of the product.

(2) cradle-to-gate quantification, also known as business to business
(B2B), includes all the GHG emissions generated up to and including the point where the product is delivered to a new organization.

\subsection{Step 2: Data Collection}

The data of products' GHGs and water resources are collected at different stages of the life cycle, including the stages of raw material input, product manufacture, transportation, use, and end of life. Because the suppliers may not provide the data, it is important to track the suppliers' ability in providing the factory data. Generally, the data sources could be categorized as two types (PAS 2050):

(1) Primary sources - first-hand information, specific to the activity in question (e.g. producing orange concentrate at plant X), collected internally or from the supply chain;

(2) Secondary sources - average, or typical, information about a general activity (e.g. juicing of oranges, concentration of juice) from a published study or other source.

\subsection{Step 3: Footprints Calculation}

(1) Carbon footprint calculation

$$
G_{i}=\left\{G_{\text {Raw }, i}+G_{M f g, i}+G_{\text {Trans }, i}\right\}
$$

where

$G_{i}$ : embedded GHG emissions of the $i^{\text {th }}$ component;

$G_{\text {Raw }, i}$ the amount of GHG emissions from the use of the raw material of the component $i\left(\mathrm{~kg} \mathrm{CO}_{2} \mathrm{e}\right)$;

$G_{M f g, i}:$ the amount of GHG emissions from the manufacturing of the component $i\left(\mathrm{~kg} \mathrm{CO}_{2} \mathrm{e}\right)$;

$G_{\text {Trans }, i}$ : the amount of GHG emissions from the transport of the component $i\left(\mathrm{~kg} \mathrm{CO}_{2} \mathrm{e}\right)$;

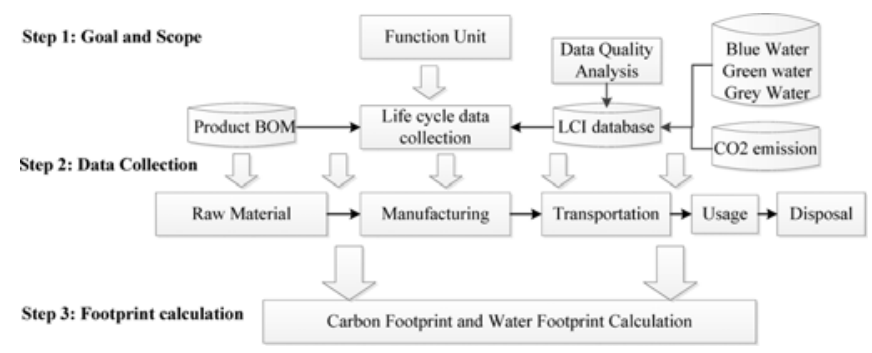

Fig. 2 The evaluation method of carbon and water footprints

Table 1 The research of carbon footprint and water footprints

\begin{tabular}{|c|c|c|c|}
\hline Footprint & Standards & Research Work & References \\
\hline \multirow{3}{*}{ Carbon footprint } & \multirow{3}{*}{$\begin{array}{l}\text { ISO/TS } 14047 \\
\text { PAS } 2050\end{array}$} & - Transitions in consumption and production patterns based on regional area & Tian et al. ${ }^{26}$ \\
\hline & & $\begin{array}{l}\text { - It calculated the product carbon footprint (PCF) and conducts an analysis of } \\
\text { energy usage for six alternative coffee products }\end{array}$ & Hassard et al. ${ }^{27}$ \\
\hline & & $\begin{array}{l}\text { - Three different refrigerants, R404A and the environmentally benign refrigerants } \\
\mathrm{R} 744\left(\mathrm{CO}_{2}\right) \text { and } \mathrm{R} 410 \mathrm{~A} \text { for various ambient temperatures are evaluated } \\
\text { based on CF }\end{array}$ & Wu et al. ${ }^{28}$ \\
\hline \multirow{3}{*}{ Water footprint } & \multirow{3}{*}{$\begin{array}{l}\text { ISO/DIS } 14046 \\
\text { The Water Footprint } \\
\text { Assessment Manu }\end{array}$} & $\begin{array}{l}\text { - The water consumption were evaluated and compared based on two } \\
\text { different fibers (cotton and Lyocell fiber) and five corresponding production } \\
\text { methods for spinning, dyeing and weaving }\end{array}$ & Chico et al. ${ }^{29}$ \\
\hline & & $\begin{array}{l}\text { - The virtual (both blue and green consumed) water trade of agricultural and } \\
\text { industrial products, but also of services }\end{array}$ & Cazcarro $^{30}$ \\
\hline & & $\begin{array}{l}\text { - The goal was to determine how to deal synergistically with environmental } \\
\text { pressure indicators in order to help building future strategies that are more } \\
\text { sustainable }\end{array}$ & Francke and Castro $^{31}$ \\
\hline
\end{tabular}


Once all the data are collected, the CF can then be calculated and the data quality monitored. The formula for carbon footprint is:

$$
\mathrm{CF}=\mathrm{A}_{d} \times \mathrm{E}_{f}
$$

where

$A_{d}$ : activity data, primary activity data

$\mathrm{E}_{f}$ : emission factor

(2) Water footprint calculation

Water footprint $=W F_{\text {proc, blue }}+W F_{\text {proc,green }}+W F_{\text {proc,grey }}$

$W F_{\text {proc,blue }}=$ Blue Water Evaporation + Blue Water Incorporation

+ Lost Return flow (volume/time)

$W F_{\text {proc,green }}=$ Green Water Evaporation

+ Green Water Incorporation (volume/time)

$W F_{\text {proc,grey }}=L / C_{\max }-C_{\text {nat }}$

where

$L: \quad$ pollutant load (mass/time)

$C_{\max }$ : the maximum acceptable concentration (mass/volume)

$C_{\text {nat }}=0$, for human-made substances that naturally do not occur in water

\subsection{Step 4: Data Quality Indicator}

Since most LCI data is collected from the on-site factories, it is difficult to find the most representative for the carbon emission and water resource. Generally, the LCI of on-site factories could be categorized as three classes: (1) the national emission factor obtained from a certain country via existing data; (2) the emission factor of industrial data obtained from a specific industry via its existing data; and (3) the emission factor obtained from a certain enterprise via its internal data. Traditionally, the DQI is used to measure the LCI data quality itself. For example, if the data quality is higher, it means the data is effective. However, the difficulties of footprint calculation are not only to choose the effective secondary data, but also to select secondary data more closely. Therefore, in this research, a mapping DQI was developed for solving the problem of secondary data selection. As shown in Table 2, DQI was extended from the pedigree matrix developed by Weidema and Wesnaes (1996). Four perspectives (reliability, time, geography, and technology) of mapping indices are developed as follows:

$$
S=\min \left\{\left|R_{1}-R_{2}\right|+\left|T i_{1}-T i_{2}\right|+\left|G_{1}-G_{2}\right|+\left|T e_{1}-T e_{2}\right|\right\}
$$

where
$R_{i}, i=1,2$, (1: the meta data of inventory, 2 : the LCI in the database)

Tii, $i=1,2$, (1: the meta data of inventory, 2 : the LCI in the database)

$G i, i=1,2$, (1: the meta data of inventory, 2 : the LCI in the database)

$T e i, i=1,2$, (1: the meta data of inventory, 2 : the LCI in the database)

\section{Case Study}

The case company is a famous manufacturer of personal computers and peripherals. In order to comply with their customer's requirement of EICC (Electronic Industry Citizenship Coalition), the company needed to disclose the information of $\mathrm{CF}$ and WF. The data used in this research were collected from January 2008 to December 2009. From the calculation of product $\mathrm{CF}$ and $\mathrm{WF}$, it was found that a total of one assembly plant and more than 100 suppliers (1076 components) were inventoried. During the inventory time, total production volume for this type is 2734 notebooks. And the total electricity used in this type of NB is around 2,115,440 kW.h $\left(1 \mathrm{~kW} \cdot \mathrm{h}=3.599712 \times 10^{6}\right.$ Joule $)$. Each NB used of the electricity rate is around $2.1859 \times 10^{-5}$. Therefore, the electricity used for each NB is $46.2431 \mathrm{Kwh}$. Most suppliers are located in Taiwan, Mainland China, and the other Asia area. For the results of CF and WF, some LCA databases had significantly different carbon and water resources in their input flows. In this model, the enterprise was able to integrate their product information, including materials, assembly proportions, weights, and amounts, relevant in-plant energy, and either the resource consumption information or the supplier information. Moreover, inventory forms were completed during data collection, and an e-mail sent to suppliers for confirmation of data accuracy.

\subsection{Goal and Scope}

Based on the CF and WF calculation guidelines, the first step was to define the system boundary. A function unit was defined as a notebook, and the system boundary was defined as "cradle to gate". The components of a notebook were broken down as its screen and main body assemblies. And the screen assembly was broken down as back cover and screen assemblies. The main body was broken down as upper cover and lower cover assemblies. All the field data of components were collected based on the CF and WF calculation.

\subsection{Data Collection}

A detailed disassembly of a notebook to its basic electronic components and parts is shown in Fig. 3.

Since no sources of information could be found to quantify water

\begin{tabular}{|c|c|c|c|c|c|}
\hline Score & 1 & 2 & 3 & 4 & 5 \\
\hline $\begin{array}{l}\text { Reliability } \\
\qquad\left(R_{i}\right)\end{array}$ & Certified & $\begin{array}{l}\text { Measured but not } \\
\text { certified }\end{array}$ & $\begin{array}{l}\text { Assumed based on the } \\
\text { theory }\end{array}$ & $\begin{array}{c}\text { Estimated based on the } \\
\text { theory or statics from an } \\
\text { area }\end{array}$ & $\begin{array}{l}\text { Estimated from the } \\
\text { subjective manner }\end{array}$ \\
\hline $\begin{array}{l}\text { Time } \\
\left(T_{i}\right)\end{array}$ & $<3$ years old & $<6$ years old & $5-10$ years old & $10-15$ years old & 15 years old \\
\hline $\begin{array}{l}\text { Geography } \\
\left(G_{i}\right) \\
\end{array}$ & $\begin{array}{c}\text { Data from the specific } \\
\text { areas or factories }\end{array}$ & $\begin{array}{c}\text { Data from the overall } \\
\text { areas or factories }\end{array}$ & $\begin{array}{c}\text { Data from the similar } \\
\text { area or factories }\end{array}$ & $\begin{array}{c}\text { Data from the less similar } \\
\text { area or factories }\end{array}$ & $\begin{array}{c}\text { Data from the different } \\
\text { area or factories }\end{array}$ \\
\hline $\begin{array}{l}\text { Technology } \\
\qquad\left(T e_{i}\right)\end{array}$ & $\begin{array}{c}\text { Data from the target } \\
\text { production line or } \\
\text { enterprise }\end{array}$ & $\begin{array}{c}\text { Data from the similar } \\
\text { production line or } \\
\text { enterprise }\end{array}$ & $\begin{array}{c}\text { Data from the average } \\
\text { area of production line or } \\
\text { enterprise }\end{array}$ & $\begin{array}{c}\text { Data from the general } \\
\text { production line or } \\
\text { enterprise }\end{array}$ & $\begin{array}{c}\text { Data from the different } \\
\text { production line or } \\
\text { enterprise }\end{array}$ \\
\hline
\end{tabular}

Table 2 Matrix of mapping data quality indicator 


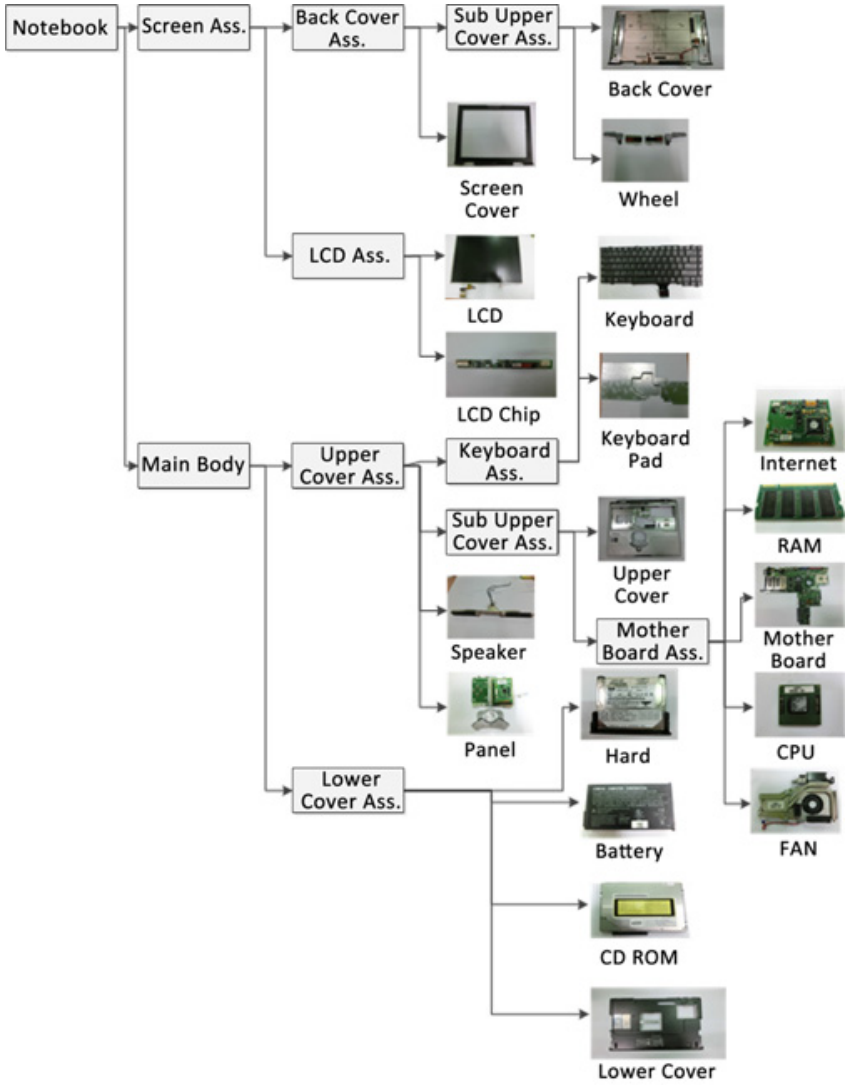

Fig. 3 A detailed disassembly of a notebook (others are omitted) intake in the raw materials extraction of the PC electronics, a more detailed BOM and primary processes information were analyzed since data could only be collected in the form of raw material masses. The ecoinvent database was used in this research since it distinguishes water resources type to groundwater, lakes, seawater, and rivers. ${ }^{37,38} \mathrm{It}$ was found that while the extraction and primary manufacturing of most materials used to produce a notebook consume relatively small amount of water, few elements largely contribute to the total amount of water consumed. Only cooling water was considered in the total estimation below as process water was presumed to be discharged back to the water stream after treatment.

\subsection{Data Quality}

The databases used in this research included Ecoinvent system processes 2.2. LCA Food DK. USLCI 1.6. Industry data 2.0. ELCD 2.0. Table 3 listed some of the raw data of the case company and the LCI database. As mentioned before, four perspectives (reliability, time, geography, and technology) were mapped and compared. For example, the raw data of Calcium oxide in the notebook, there are three choices of the 2nd source data, Lime (burnt) ETH S, Quicklime at plant/US, and Quicklime- milled, loose, at plant/CH S in the databases. The DQIs of these three choices are 14,14, and 12. Because the smallest DQI is better, Quicklime- milled, loose, at plant/CH S in the database of Ecoinvent system processes 2.2 was selected. The similar criteria were applied for the Capacitor. The case company could directly determine the emission coefficient and water resource from the database.

Table 3 Part demonstration of DQIs for the case study

\begin{tabular}{|c|c|c|c|c|c|c|}
\hline $\begin{array}{l}\text { Raw data of Case } \\
\text { company }\end{array}$ & $\begin{array}{c}2^{\text {nd }} \text { data } \\
\text { Available emission coefficient }\end{array}$ & Reliability & Time & Geography & Technology & DQIs \\
\hline \multirow{6}{*}{ Calcium oxide } & \multirow[t]{2}{*}{ Lime (burnt) ETH S } & LCA Food DK & 1997 & USA & $\begin{array}{l}\text { Data from the average area of } \\
\text { production line }\end{array}$ & \multirow[t]{2}{*}{14} \\
\hline & & 2 & 5 & 4 & 3 & \\
\hline & \multirow[t]{2}{*}{ Quicklime, at plant/US } & USLCI 1.6 & NA & USA & $\begin{array}{l}\text { Data from the average area of } \\
\text { production line }\end{array}$ & \multirow[t]{2}{*}{14} \\
\hline & & 2 & 5 & 4 & 3 & \\
\hline & \multirow{2}{*}{$\begin{array}{l}\text { Quicklime, milled, loose, } \\
\text { at plant/CH S }\end{array}$} & ESP 2.2 & NA & Swiss & Data comes from Swiss & \multirow{2}{*}{$12^{*}$} \\
\hline & & 2 & 5 & 4 & 1 & \\
\hline \multirow{4}{*}{ Capacitor } & \multirow{2}{*}{$\begin{array}{l}\text { Capacitor, SMD type, } \\
\text { surface-mounting, } \\
\text { at plant/GLO S }\end{array}$} & ESP 2.2 & NA & Global & $\begin{array}{l}\text { Data from the average area of } \\
\text { production line }\end{array}$ & \multirow[t]{2}{*}{$15^{*}$} \\
\hline & & 2 & 5 & 5 & 3 & \\
\hline & \multirow{2}{*}{$\begin{array}{l}\text { Capacitor, unspecified, } \\
\text { at plant/GLO S }\end{array}$} & ESP 2.2 & NA & Global & Data from the different production line & \multirow{2}{*}{17} \\
\hline & & 2 & 5 & 5 & 5 & \\
\hline \multirow{10}{*}{ Copper } & \multirow{2}{*}{$\begin{array}{l}\text { Copper, primary, } \\
\text { at refinery/GLO S }\end{array}$} & ESP 2.2 & 1994 & Global & $\begin{array}{l}\text { Data from the average area of } \\
\text { production line }\end{array}$ & \multirow[t]{2}{*}{15} \\
\hline & & 2 & 5 & 5 & 3 & \\
\hline & \multirow{2}{*}{$\begin{array}{l}\text { Copper, primary, } \\
\text { at refinery/ID S }\end{array}$} & ESP 2.2 & 1994 & India & $\begin{array}{l}\text { Data from the average area of } \\
\text { production line }\end{array}$ & \multirow[t]{2}{*}{13} \\
\hline & & 2 & 5 & 3 & 3 & \\
\hline & \multirow{2}{*}{$\begin{array}{l}\text { Copper, primary, } \\
\text { at refinery/RAS S }\end{array}$} & ESP 2.2 & 1994 & Asia area & $\begin{array}{l}\text { Data from the average area of } \\
\text { production line }\end{array}$ & \multirow[t]{2}{*}{$12^{*}$} \\
\hline & & 2 & 5 & 2 & 3 & \\
\hline & \multirow{2}{*}{$\begin{array}{l}\text { Copper, primary, } \\
\text { at refinery/RER S }\end{array}$} & ESP 2.2 & 1994 & Europe & $\begin{array}{l}\text { Data from the average area of } \\
\text { production line }\end{array}$ & \multirow[t]{2}{*}{14} \\
\hline & & 2 & 5 & 4 & 3 & \\
\hline & \multirow{2}{*}{$\begin{array}{l}\text { Copper, primary, } \\
\text { at refinery/RLA S }\end{array}$} & ESP 2.2 & 1994 & Latin area & $\begin{array}{l}\text { Data from the average area of } \\
\text { production line }\end{array}$ & \multirow[t]{2}{*}{14} \\
\hline & & 2 & 5 & 4 & 3 & \\
\hline
\end{tabular}




\subsection{CF and WF Calculations}

Table 3 indicates the suitable emission coefficient of $\mathrm{CF}$ calculations for the case company. As shown in Table 4, CF for the main body and screen assembly was 18.05 and 4.88 CO2e-kg, respectively. The GHG of manufacturing (34.66 CO2e-kg) is collected based on job shop manufacturing data. The blue water footprints were 131.5 and $11.9 \mathrm{~m}^{3}$ for the main body and screen assembly, respectively.

It was found that the carbon emission was related to water resources for the notebook. The more of carbon emission was, the higher of water resource demanded. Fig. 4 presented that the mother board used the highest water resources and generated the highest carbon emission. This was resulted from a CD ROM built in the lower cover of the

Table 4 The results of carbon and water footprints

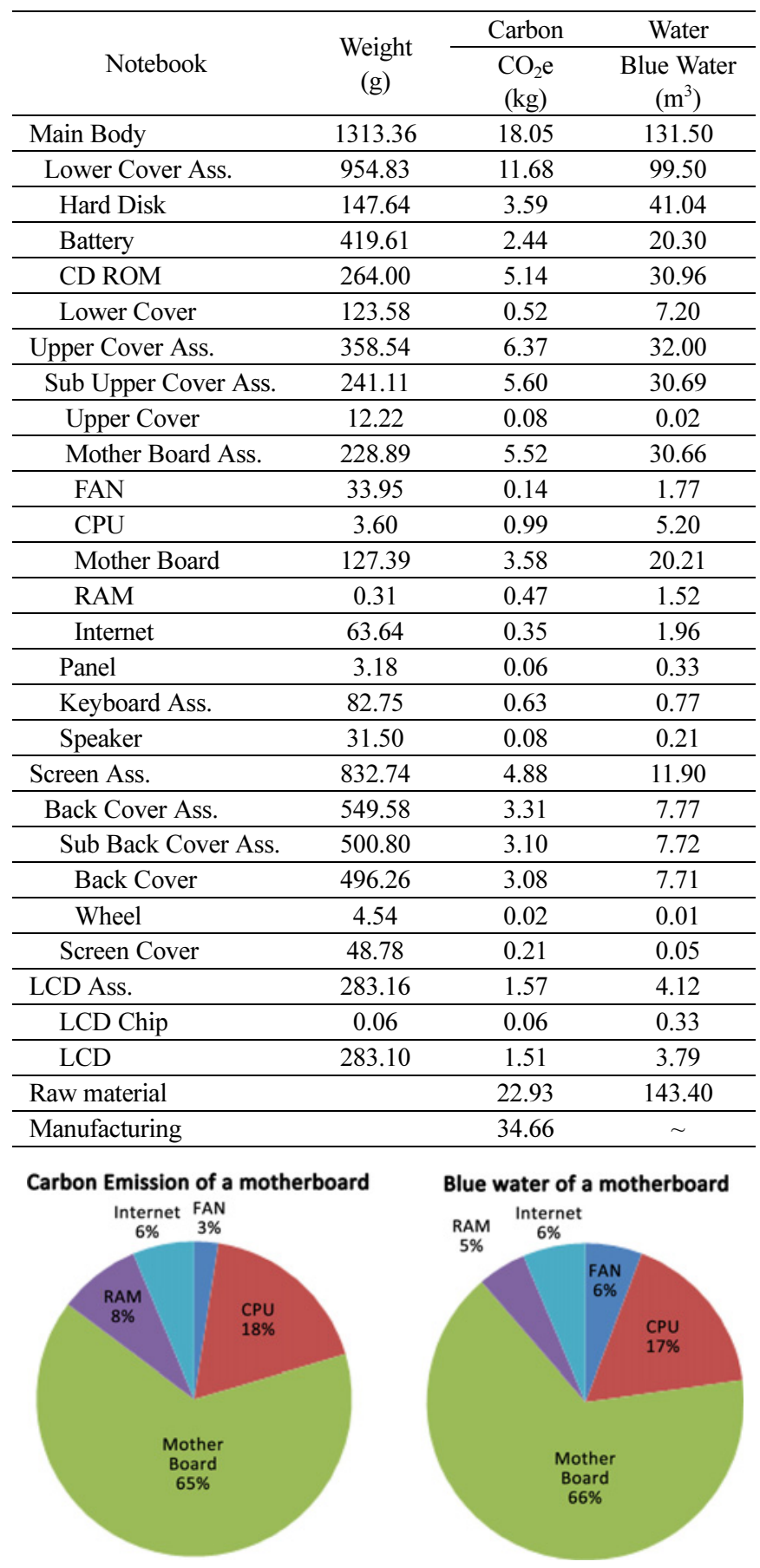

Fig. 4 The carbon emission, blue water of a mother board mother board. If the CD ROM is not the standard equipment of notebooks, the carbon and blue water footprints were cut down 5.14 CO2e-kg and $30.96 \mathrm{~m} 3$, respectively. For the grey water, it includes the biochemical oxygen demand (BOD), chemical oxygen demand (COD), and suspended solid (SS). The detailed grey water footprint of the mother board is also shown by \% in Fig. 4. Among the mother board, it could be found that the chip has the highest carbon emission (60.54\%), water usage (42.57\%), BOD (67.38\%), and COD (67.1\%). The capacitor has the highest SS (47.73\%) of the mother board. Therefore, a redesigned chip is the critical component of the ecological footprints for a notebook. Furthermore, the result is also shown that DQI is improved about $5.7 \%$ for the carbon footprint calculation.

\section{Conclusions}

As the issues concerning GHGs and water resources have gradually attracted the attention of enterprises, carbon footprint and water footprint disclosure have become more and more common. With such a pressure, enterprises had developed some techniques and accumulated experiences about carbon and water footprints inventories, but still failed to meet the demand. The main reason is that it is very time consuming to disclose these information. And the enterprises hope to use a simple and rapid method to assist them in finding the direction for carbon and water reduction.

In this study, first, a hybrid system was proposed to get carbon and water footprints simultaneously. Second, the development of this system included determining a functional unit of a notebook, analyzing product BOM information, and giving the designer feedback on product footprints' BOM, and assisting in system design and development. Third, although, only the cradle to gate is conducted, the results have shown that the system could indeed reduce enterprises' investment in manpower and resources of footprints inventories, and decrease the inventory time, and enhance data accuracy. In the future, many aspects of this study still call for improvement. It could be improved by integrating this study with the laws and regulations and guiding principles of footprints' inventory and with the CAD system at the R\&D stage.

\section{ACKNOWLEDGEMENT}

This research is partially supported by Ministry of Science Technology of the Republic of China, Taiwan under contract 102-2622E-033-002-CC3 and 102-2221-E-033-024.

\section{REFERENCES}

1. Wackernagel, M., Onisto, L., Bello, P., Linares, A. C., Falfán, I. S. L., et al., "National Natural Capital Accounting with the Ecological Footprint Concept," Ecological Economics, Vol. 29, No 3, pp.375390, 1999.

2. Chen, M.-K. and Pai, K.-H., "The Customer Chain Operation Reference Model for the Mainboard Industry," Journal of Industrial and Production Engineering, Vol. 31, No. 4, pp. 207-219, 2014. 
3. Ma, Y.-F., Chen, L.-W., Meng, S.-D., and Yi, C.-Q., "A Study on the Risk Control of Supply Chain under the Background of Globalization," Journal of Industrial and Production Engineering, Vol. 31, No. 4, pp. 221-228, 2014.

4. Kuo, T. C., Chen, G. Y.-H., Wang, M. L., and Ho, M. W., "Carbon Footprint Inventory Route Planning and Selection of Hot Spot Suppliers," International Journal of Production Economics, Vol. 150, pp. 125-139, 2014.

5. Manzardo, A., Ren, J., Piantella, A., Mazzi, A., Fedele, A., et al., "Integration of Water Footprint Accounting and Costs for Optimal Chemical Pulp Supply Mix in Paper Industry,” Journal of Cleaner Production, Vol. 72, pp. 167-173, 2014.

6. Su, J. C., Chu, C.-H., and Wang, Y.-T., “A Decision Support System to Estimate the Carbon Emission and Cost of Product Designs," Int. J. Precis. Eng. Manuf., Vol. 13, No. 7, pp. 1037-1045, 2012.

7. Ahn, S.-H., "An Evaluation of Green Manufacturing Technologies Based on Research Databases," Int. J. Precis. Eng. Manuf.-Green Tech., Vol. 1, No. 1, pp. 5-9.

8. Qi, C. and Chang, N.-B., "Integrated Carbon Footprint and Cost Evaluation of a Drinking Water Infrastructure System for Screening Expansion Alternatives," Journal of Cleaner Production, Vol. 60, pp. 170-181, 2013.

9. IPCC, "Climate Change 2007: Synthesis Report," Intergovernmental Panel on Climate Change, 2007.

10. Cazcarro, I., Hoekstra, A., and Sanchez, C. J., "The Water Footprint of Tourism in Spain,” Tourism Management, Vol. 40, pp. 90-101, 2014.

11. Coca Cola Carbon Footprint, "Coca Cola Wants Your Rubbish," http:// www.coca-cola.co.uk/environment/coca-cola-recycle-zones.html (Accessed 24 November 2014)

12. The Coca Cola Company, "Product Water Footprint Assessments," http:/ /assets.coca-colacompany. com/6f/61/43df76c8466d97c073675d1c5f65/ TCCC_TNC_Water FootprintAssessments.pdf (Accessed 24 November 2014)

13. Jensen, A. A., Hoffman, L., Møller, B. T., Schmidt, A., Kim, C., et al., "Application of Life Cycle Assessments (LCA): Report from Expert Workshop at Hankø, Norway on LCA in Strategic Management, Product Development and Improvement, Marketing and Ecolabelling and Governmental Policies," Nordic Project on Environmentally Sound Product Development Report, No. 6, 1995.

14. Hailes, J. and Elkington, J., "The LCA Sourcebook. A European Business Guide to Life-Cycle Assessment," SustainAbility, 1993.

15. Baumann, H. and Tillman, A. M., "The Hitchhiker's Guide to Life Cycle Assessment," Studentlitteratur AB, 2004.

16. Chiu, M. C. and Chu, C. H., "Review of Sustainable Product Design from Life Cycle Perspectives,” Int. J. Precis. Eng. Manuf., Vol. 13, No. 7, pp. 1259-1272, 2012.

17. Finkbeiner, M., "Carbon Footprinting-Opportunities and Threats," The International Journal of Life Cycle Assessment, Vol. 14, No. 2, pp. 91-94, 2009.
18. Weidema, B. P. and Wesnæs, M. S., "Data Quality Management for Life Cycle Inventories-An Example of using Data Quality Indicators," Journal of Cleaner Production, Vol. 4, No. 3, pp. 167-174, 1996.

19. PAS 2050: 2008, "Specification for the Assessment of the Life Cycle Greenhouse Gas Emissions of Goods and Services," British Standards Institution, 2008.

20. Rugrungruang, F., Chua, B. H., and Low, S. C., "Development of Product Carbon Footprint Assessment: A Step towards Sustainability for Singapore Manufacturing Industry," SIMTech Technical Reports, Vol. 10, No. 2, 2009.

21. Lee, K.-H., "Integrating Carbon Footprint into Supply Chain Management: The Case of Hyundai Motor Company (HMC) in the Automobile Industry," Journal of Cleaner Production, Vol. 19, No. 11, pp. 1216-1223, 2011.

22. Fleten, S.-E., Lien, K., Ljønes, K., Pagès-Bernaus, A., and Aaberg, M., "Value Chains for Carbon Storage and Enhanced Oil Recovery: Optimal Investment under Uncertainty," Energy Systems, Vol. 1, No. 4, pp. 457-470, 2010.

23. Ercin, A. E. and Hoekstra, A. Y., "Water Footprint Scenarios for 2050: A Global Analysis," Environment International, Vol. 64, pp. 71-82, 2014.

24. Hoekstra, A. Y., "Virtual Water Trade," Proc. of the International Expert Meeting on Virtual Water Trade, No. 12, 2003.

25. Chapagain, A. K. and Hoekstra, A. Y., "Water Footprints of Nations," Value of Water Research Report Series, No. 16, 2004.

26. Tian, X., Chang, M., Lin, C., and Tanikawa, H., "China's Carbon Footprint: A Regional Perspective on the Effect of Transitions in Consumption and Production Patterns," Applied Energy, Vol. 123, pp. 19-28, 2014.

27. Hassard, H., Couch, M., Techa-Erawan, T., and McLellan, B., "Product Carbon Footprint and Energy Analysis of Alternative Coffee Products in Japan,” Journal of Cleaner Production, Vol. 73, pp. 310-321, 2014.

28. Wu, X., Hu, S., and Mo, S., "Carbon Footprint Model for Evaluating the Global Warming Impact of Food Transport Refrigeration Systems," Journal of Cleaner Production, Vol. 54, pp. 115-124, 2013.

29. Chico, D., Aldaya, M. M., and Garrido, A., “A Water Footprint Assessment of a Pair of Jeans: The Influence of Agricultural Policies on the Sustainability of Consumer Products," Journal of Cleaner Production, Vol. 57, No. 15, pp. 238-248, 2013.

30. Cazcarro, I., Hoekstra, A. Y., and Chóliz, J. S., "The Water Footprint of Tourism in Spain,” Tourism Management, Vol. 40, pp. 90-101, 2014.

31. Francke, I. and Castro, J., "Carbon and Water Footprint Analysis of a Soap Bar Produced in Brazil by Natura Cosmetics," Water Resources and Industry, Vols. 1-2, pp. 37-48, 2013.

32. Li, J. S. and Chen, G. Q., "Water Footprint Assessment for Service Sector: A Case Study of Gaming Industry in Water Scarce Macao," Ecological Indicators, Vol. 47, pp. 164-170, 2014. 
33. Jefferies, D., Muñoz, I., Hodges, J., King, V. J., Aldaya, M., et al., "Water Footprint and Life Cycle Assessment as Approaches to Assess Potential Impacts of Products on Water Consumption. Key Learning Points from Pilot Studies on Tea and Margarine,” Journal of Cleaner Production, Vol. 33, pp. 155-166, 2012.

34. Wang, E. and Shen, Z., "A Hybrid Data Quality Indicator and Statistical Method for Improving Uncertainty Analysis in LCA of Complex System: Application to the Whole-Building Embodied Energy Analysis," Journal of Cleaner Production, Vol. 43, pp. 166173, 2013.

35. Weidema, B. P. and Wesnæs, M. S., "Data Quality Management for Life Cycle Inventories-An Example of using Data Quality Indicators," Journal of Cleaner Production, Vol. 4, No. 3, pp. 167174,1996

36. Ciroth, A., "Cost Data Quality Considerations for Eco-Efficiency Measures," Ecological Economics, Vol. 68, No. 6, pp. 1583-1590, 2009.

37. Bayart, J.-B., Bulle, C., Deschênes, L., Margni, M., Pfister, S., et al., "A Framework for Assessing Off-Stream Freshwater Use in LCA," The International Journal of Life Cycle Assessment, Vol. 15, No. 5, pp. 439-453, 2010.

38. Koehler, A., "Water Use in LCA: Managing the Planet's Freshwater Resources," The International Journal of Life Cycle Assessment, Vol. 13, No. 6, pp. 451-455, 2008. 